\title{
Do 90 percent of terrorist groups last less than a year? Updating the conventional wisdom
}

\author{
Version accepted at Terrorism and Political Violence \\ July 2017 \\ Brian J. Phillips \\ brian.phillips@cide.edu
}

\begin{abstract}
Prominent scholars criticize terrorism research for lacking sufficient empirical testing of arguments. Interestingly, one of the most widely-cited estimates in terrorism studies has not been evaluated using the many data sources now available. Rapoport's 1992 claim, that perhaps 90 percent of terrorist groups last less than one year, has been described as part of the conventional wisdom. This estimate is frequently used to justify studies of terrorist group longevity, a substantial line of research in recent years. Is the estimate accurate? Scholars increasingly publish data sets of terrorist organizations, but no one has analyzed them collectively to see if the 90 percent claim holds up. This article examines the eight largest global data sets of terrorist group longevity, covering 1968-2013. The samples vary considerably, but the percent of groups that do not survive beyond their first year in these relevant data sets is between 25-74 percent. Across all data sets, on average about 50 percent of terrorist organizations do not make it past their first year. There is some variation depending on group motivations, consistent with Rapoport's "wave" theory. However, overall, terrorist organizations appear to be more durable than the conventional wisdom suggests.
\end{abstract}

I thank David C. Rapoport for helpful comments on an earlier draft. I also thank Laura Dugan, Khusrav Gaibulloev, Martin Libicki, Erin Miller, Todd Sandler, and Jodi Vittori for sharing data, and Andrea Marín Serrano for research assistance. 
Terrorism research suffers from a number of issues, including, as Crenshaw argues, a "need for integrative and cumulative theory." "A related matter is that terrorism studies has lagged behind other areas of research in its use of hard data, whether descriptive or inferential. ${ }^{2}$ Sageman contends that terrorism research contains an "explosion of speculations with little empirical grounding."”3 The conventional wisdom on terrorism has included claims that, when subjected to substantial and repeated empirical testing, have not always found support. For example, the relationship between democracy and terrorism is not as clear as it once seemed. ${ }^{4}$ Additionally, the supposed lack of a relationship between mental illness and terrorism is not so simple - when it comes to lone-actor terrorism. ${ }^{5}$ At least one claim in the conventional wisdom has never been the focus of empirical testing, and that is the motivation for this manuscript.

One of the most widely-cited statistics in terrorism studies is that 90 percent of terrorist groups last less than one year. This estimate was first made by David Rapoport in a 1992 encyclopedia article, before global data sets of terrorist groups existed. ${ }^{6}$ It has been cited by a host of other important terrorism scholars such as Byman, Cronin, Hoffman, Sandler, Silke, and Stern. ${ }^{7}$ It has been described as "the conventional wisdom" regarding terrorist group longevity. ${ }^{8}$ Other scholars refer to it as the "oft-quoted phrase," "oft-cited guestimate," or "well-known conjecture." The statistic is frequently used to justify research on terrorist group longevity, a substantial line of work in recent years. However, to what extent is this statement accurate? Since the 1990s, a number of data sets of terrorist organizations have been published, but no one has collectively analyzed them to see to what extent the 90 percent claim holds up. ${ }^{10}$

The question of terrorist group longevity, and specific data about average survival time, is important for a number of reasons. If so many groups are indeed flashes in the pan, 
instead of studying specific groups it might make more sense to study different units of analysis, such as broader social movements from which groups emerge, lone wolves and small cells, or entire conflicts instead of particular organizations. Regarding policy, if terrorist groups usually do not have substantial lifespans, then policies such as leadership decapitation might often be unnecessary.

The rest of this manuscript proceeds as follows. First, the context of the 90 percent quote is discussed, as well as its repetition in later studies. Second, eight of the largest global data sets of terrorist groups are examined, to see what percent of groups do not survive past their first year. The samples of terrorist groups vary considerably. However, the percent of groups that do not survive beyond their first year, in these relevant global sets of terrorist groups, is between 25-74 percent. The average first-year failure rate across the data sets is about 50 percent. This suggests terrorist groups are more durable than the conventional wisdom indicates. Some of Rapoport's related claims do find support, such as the notion that left-wing or "third wave" groups are especially failure-prone, and the idea that many groups that survive through their first year do not make it to their tenth. The conclusion offers suggestions for future research.

\section{A famous statistic in the terrorism literature}

Rapoport's statement about longevity in the 1992 encyclopedia article is worth quoting in its entirety:

Modern terrorist organizations, in contrast to their ancient counterparts, do not survive long. Perhaps as many as 90 percent last less than a year. Nearly half of those which persist beyond the first year are out of existence by the tenth. ${ }^{11}$ 
The statement was then repeated in a variety of terrorism studies, including research by some of the most visible scholars. Bruce Hoffman states, in his classic book Inside Terrorism, "David Rapoport, for example, estimates that the life expectancy of 90 percent of terrorist organizations is less than a year, and that nearly half the ones that make it that far cease to exist within a decade." ${ }^{12}$ Similarly, Audrey Cronin repeats the statement in her International Security article on terrorist group longevity. ${ }^{13}$ It is noteworthy that Cronin also suggests that the claim "needs to be updated." These are a few examples, but searches of academic articles and books reveal that dozens of other studies repeat Rapoport's claim. $^{14}$

Interestingly, some studies that mention the 90 percent statistic cite secondary sources instead of the original Rapoport piece. ${ }^{15} \mathrm{~A}$ few articles mention the statistic without any citation. These kinds of issues of course happen with citations, but they point to the widespread "conventional wisdom" nature of this figure. They also illustrate how citation counts of Rapoport's encyclopedia entry probably underestimate its true impact. It is difficult to know precisely how many times the 1992 encyclopedia article has been cited. Books and book sections are notoriously undercounted by academic search engines.

Few if any terrorism statistics are more widely cited than Rapoport's 90 percent estimate. Other possibilities include the 9/11 Commission's evaluation that the Sept. 11, 2001 , attacks cost around $\$ 500,000$, which was repeated in many popular and academic publications. ${ }^{16}$ Pape's comment that suicide attacks kill 12 times more people than nonsuicide attacks has also been repeated widely. ${ }^{17}$ Rapoport's estimate appears to be comparable with these commonly-cited claims.

Beyond the original "90 percent" estimate 
Beyond Rapoport's 90 percent estimate, there are several related claims that are also important to recognize. First, as is indicated in the full quote above, Rapoport also states that of those groups that survive the first year, almost 50 percent will not survive to 10 years. This claim is difficult to evaluate because it is about the survival patterns of the approximately 10 percent of groups that complete their first year, when - as this manuscript will show - that 10 percent figure does not seem to be accurate. Given the debatable premise, there is uncertainty about what sample of groups to analyze to see if they make it to 10 years. Additionally, to know which groups survived up to 10 years, one would need to only analyze groups founded at least 9 years before the end of the sample. This would substantially truncate samples. However, the 10 -year survival claim is briefly examined below in case some readers are interested.

Second, Rapoport's claim about 90 percent of groups not surviving past one year appeared, as noted, in his 1992 encyclopedia article. However, in the 2004 edition, Rapoport estimates that 90 percent of "third-wave" (leftist) groups do not survive a year. The updated version of the encyclopedia article does not make a claim about terrorist groups generally, only leftist groups. This update has not been noticed by most of the scholars who cite Rapoport's 1992 article. The empirical section also briefly evaluates this claim about third-wave groups. Finally, in the updated 2004 version of Rapoport's article, he also mentions that "ethnic groups are the most durable because their constituencies are the most stable." ${ }^{, 18}$ Rapoport also argues that religious groups "ultimately may be much more durable," compared to earlier waves. ${ }^{19}$ The empirical section considers these claims as well. However, most of this manuscript focuses on the 1992 estimate, about terrorist groups in general, since this is the statement that is widely quoted in the literature. 


\section{Empirical analysis}

To evaluate the 90 percent estimate, this section examines the largest global data sets of terrorist organizations. This is the best way to test assertions about terrorist groups in general. The data sets analyzed are those that sought to gather information about as many terrorist groups around the world as possible - essentially, the "universe" of terrorist groups. Beyond these data sources, other data sets have restricted their sample to only groups that, for example, have carried out a certain minimum number of attacks. ${ }^{20}$ As a result, shorter-lived groups are likely to be excluded. If these more selective databases were included, this would bias results toward finding a very low percentage of groups that last less than a year. Table 1 provides summary information about the databases analyzed.

[Table 1 about here.]

The primary databases analyzed, in order of year of publication, are Jones and Libicki's data on 648 groups; Vittori's random sample of 100 groups (from a larger sample of 897); Blomberg, Engel, and Sawyer's study of 1,414 groups; Dugan's analysis of 2,103 groups; Gaibulloev and Sandler's information on 586 groups; My own data on 633 groups; Young and Dugan's study of 2,223 organizations, and Miller's analysis of 2,437 organizations. $^{21}$

Jones and Libicki sought to gather information on every terrorist group in the world between 1968 and 2006, primarily using the RAND-MIPT Terrorism Incident database. This appears to be the most influential database of terrorist groups, cited hundreds of times according to Google Scholar. Additionally, other scholars have used the Jones and Libicki

data for their own analyses of group longevity. ${ }^{22}$ Vittori sought to gather information on 
every terrorist group between 1968 and 2007. She used the Terrorism Knowledge Base (TKB), which relied on RAND-MIPT data and the American Terrorism Study Indictment Database. This produced 897 groups, but given challenges with coding information for so many groups, she focused on a random sample of 100 organizations.

Blomberg et al. use the International Terrorism: Attributes of Terrorist Events (ITERATE) data to gather information on groups that have carried out at least one transnational attack between 1968-2007. Transnational attacks can imply the group travelling to another country, but more often refer to local attacks on "international" targets such as a consulate or visiting dignitary. Therefore, we should be careful about applying inferences drawn from the Blomberg et al. transnational terrorist group data to "terrorist groups" more broadly. However, many groups, even groups we might think of fundamentally "domestic," carry out at least one transnational attack, so the data set includes many important groups.

Dugan analyzed a data set of all 2,013 organizations associated with attacks in the GTD, 1970-2007. She notes that most of the groups, 1,493, were active less than a year. Gaibulloev and Sandler also published a data set of terrorist groups from 1970-2007, drawing on RAND and Jones and Libicki's data. They end up with 586 groups, fewer than other researchers using similar sources. They indicate that this is because RAND sometimes includes different variations of group's name as separate groups, and Gaibulloev and Sandler remove these repeat "groups.",23

My own data set of 633 groups covered 1987-2005, using information from a number of sources. Asal and Rethemeyer's group data, based on the TKB, was used for $1998-2005 .^{24}$ For earlier years, the TKB, the Global Terrorism Database (GTD) attack data, as well as Lexis-Nexis searches, were used. Young and Dugan's data is similar to Dugan's, 
but with some refinements. They used GTD data and identify 2,223 terrorist groups, a few more than Dugan originally reported. Miller's data is also GTD-based, and the largest sample used, with 2,437 groups between 1970 and 2013. Overall, the Dugan, Young and Dugan, and Miller data sets can be considered GTD data, but minor differences result from distinct cleaning and coding decisions. There is no official "GTD terrorist group" data set.

Table 1 shows, for each of the data sets described above, what percent of terrorist groups do not survive beyond their first year. None of the databases provides support for the idea that 90 percent of groups do not survive past their first year. The percent of groups that do not make it past year one are between $25-74$ percent. The average value across the eight data sets is 52 percent. This is considerably lower than Rapoport's estimate. There is substantial variation in the samples in terms of their first-year failure rates. In Dugan's sample, 74 percent of groups last a year or less. However, there are also several data sets where the rate is less than 30 percent. Instead of relying on one database, the 52 percent average is a rough, but helpful, indication of first-year failure patterns among major terrorist group data collections.

Why is there such substantial variation in longevity patterns across data sets? Any effort to gather data on terrorism, or terrorist groups, is fraught with challenges. Researchers must decide what is "terrorism," then what is a "terrorist group." Specific groups must be identified, as opposed to multiple aliases for the same group, lone-actors that claim their attacks with the name of a group. Additionally, decisions must be made about whether a group is a faction or cell of a larger group, or if it is its own group. Researchers also have to decide what year a group actually "started" and "ended," which is more complicated than some readers might realize. In general, there are difficulties with 
finding information about clandestine groups. As a result, it makes some sense that different researchers would build databases with such divergent results.

However, it is interesting that the three data sets with the lowest first-year failure rates all use RAND data. By contrast, the three data sets with the highest first-year failure rates (Dugan, Miller, and Young and Dugan) use GTD data. Some reasons for variation based on data source are discussed below, in particular the size of the GTD. Different data sources will produce distinct results, and researchers should keep this in mind.

Sample size seems to be related to longevity. The data sets by Jones and Libicki, Gaibulloev and Sandler, and Phillips include fewer terrorist organizations than the others. It is probably not a coincidence that the data sets with fewer terrorist groups also find longer duration. Narrower definitions of "terrorist group," and the related smaller samples, are usually associated with longer group duration. ${ }^{25}$ In general, smaller samples might be missing some legitimate groups, and it seems probable that small, short-lived groups would be the most likely to be overlooked. If the Jones and Libicki, Gaibulloev and Sandler, and Phillips data are removed from this analysis, the average percent of first-year failure rises to 68 percent. This is high, but still rather far from Rapoport's 90 percent estimate.

A flip side of these sample selection concerns, however, is that it is possible that the larger terrorist group databases include some non-groups, such as aliases, or groups better thought of as a cell within a larger group. Additionally, the GTD, the source for the three largest data sets, includes attacks by some groups that are not commonly thought of as “terrorist groups," such as drug-trafficking organizations. ${ }^{26}$ These issues raise questions about whether bigger is necessarily better with terrorist group databases. However, it is difficult to know which database is the most accurate reflection of reality, and therefore 
looking at multiple sources is helpful to try to understand patterns of terrorist group survival - or any other organizational characteristics.

\section{Additional claims: 10-year survival and third-wave groups}

Do nearly half of all groups that survive past their first year end before their tenth year? This claim is more difficult to evaluate, for reasons discussed above. However, analysis of the available data suggests there is some support for this claim. For example, in the Jones and Libicki and Phillips data sets, more than half of the groups that survived their first year did not make it to their tenth (62 and 58 percent, respectively). The percentage is higher in Dugan's GTD data, where 78 percent of the groups living past their first year did not last until their tenth year. However, in the Gaibulloev and Sandler data, only 35 percent of the groups surviving their first year go out of business before turning 10. Overall, then, there is some support for Rapoport's less-quoted assertion that a about half of terrorist groups surviving past a year do not make it until their tenth birthday.

Regarding Rapoport's 2004 claim that 90 percent of third-wave groups did not last a year, the extant data sources do not provide support for such a high percentage. None of the data sets explicitly codes third-wave groups, but four have a motivation or ideology variable that codes some groups as left-wing or leftist. The data sets also include other categories, such as ethnic (also referred to as "nationalist") and religious groups, which Rapoport argued should be especially resilient.

[Figure 1 about here.] 
Figure 1 shows the first-year failure rates for left-wing groups vs. other types of group based on their motivations. In the four samples with such data, left-wing groups are indeed more likely to fail in their first year than other group types. In the Jones and Libicki data, left-wing groups have a 29 percent first-year failure rate, while the rates are 27 and 18 percent respectively for religious and ethnic groups. The Vittori data suggests 67 percent of leftist groups last a year or less, whereas 61 percent of ethnic groups and 55 percent of religious groups end so quickly. In the Gaibulloev and Sandler data, while 30 percent of left-wing groups end in their first year, only 27 and 21 percent of ethnic and religious groups do so. The Phillips data suggests a sharper difference, where 33 percent of leftist groups do not last longer than a year, while the numbers are 12 percent for ethnic groups and 17 percent for religious groups.

The data suggest ethnic groups are somewhat more durable than left-wing groups, but in three of the four data sets the difference is small. In all the data sets, religious groups are less likely to end in the first year than left-wing groups are, consistent with Rapoport's argument. Interestingly, right-wing group are also especially unlikely to cease to exist in their first year. This is not a part of Rapoport's wave theory, and right-wing groups are a fairly rare type of group, but more research into the apparent longevity of right-wing groups could be fruitful. ${ }^{27}$

These descriptive-data trends are consistent with other analysis. Quantitative multivariate analysis results are mixed, but some studies find that ethnonationalist motivations are associated with group longevity. ${ }^{28}$ Other quantitative studies find religious groups are especially long-lasting. ${ }^{29}$ Overall, there is no support for the idea that 90 percent of leftist groups failed before their first birthday. However, consistent with Rapoport's 
arguments, there is some support for the idea that left-wing groups are not especially resilient, while religious and ethnic groups are.

\section{Conclusion}

Rapoport's estimate that perhaps 90 percent of terrorist groups survive less than a year has drawn attention to an important subject, terrorist group longevity, and more generally to organizational dynamics of terrorism. It has provided impetus to theoretical and empirical work on the subject, and has contributed to the inspiration for major datagathering projects on terrorist organizations. It is fitting, then, that these major data collections are used to evaluate the conventional wisdom about terrorist group longevity.

Analysis of the eight most expansive global data sets of terrorist organization longevity suggests that terrorist groups are more durable than commonly thought. While prominent terrorism studies repeat the claim that 90 percent of terrorist groups last less than a year, it turns out that perhaps about 50 percent of terrorist groups are so short-lived. This broad range of first-year failure rates across data sets is indicative of challenges in obtaining data about clandestine organizations, and how researchers can come to different conclusions even using similar data sources. However, it is remarkable that the statistics are all considerably below 90 percent.

Given that terrorist groups are apparently more durable than we had believed, this carries implications for research on terrorist organizations. The population of terrorist groups is not only a handful of unusually durable groups, and the rest that last less than a year. Case studies of terrorist organizations tend to focus on the extremely durable groups that have lasted decades. However, we probably ought to learn more about the other terrorist groups, which tend to carry out attacks for a few years, if not 10 or 15. 
The apparent gap between the conventional wisdom and the data suggests the importance of complementing theoretical work with additional empirical analysis. For example, researchers continue to test Bloom's outbidding argument as new data becomes available. ${ }^{30}$ Testing the limits of arguments, and the conditions under which arguments hold, is an important part of building a more cohesive body of terrorism research. It is also consistent with calls to bring more data analysis, even descriptive data, into terrorism studies. ${ }^{31}$ There are debates about the relative merits of theory generation vs. hypothesis testing, ${ }^{32}$ but both are necessary as the field of terrorism studies progresses. 
Table 1. Data sets used to analyze the "90 percent" estimate

\begin{tabular}{|c|c|c|c|}
\hline Study & Description of sample & Source(s) & $\begin{array}{l}\text { Percent of groups } \\
\text { that survive } 1 \\
\text { year or less }\end{array}$ \\
\hline $\begin{array}{l}\text { Jones and Libicki } \\
2008\end{array}$ & $\begin{array}{l}648 \text { groups. Global, 1968- } \\
2006\end{array}$ & RAND & $25 \%$ \\
\hline Vittori 2009 & $\begin{array}{l}100 \text { groups. A random sample } \\
\text { of } 897 . \text { Global, 1968-2007. }\end{array}$ & RAND & $59 \%$ \\
\hline $\begin{array}{l}\text { Blomberg et al. } \\
2010\end{array}$ & $\begin{array}{l}\text { 1,414 groups. Global, but only } \\
\text { groups with transnational } \\
\text { attacks. } 1968-2007 .\end{array}$ & ITERATE & $67 \%$ \\
\hline Dugan 2012 & $\begin{array}{l}2,103 \text { groups. Global, 1970- } \\
2007 .\end{array}$ & GTD & $74 \%$ \\
\hline $\begin{array}{l}\text { Gaibulloev and } \\
\text { Sandler } 2013\end{array}$ & $\begin{array}{l}586 \text { groups. Global, 1970- } \\
2007 .\end{array}$ & $\begin{array}{l}\text { RAND and } \\
\text { Jones and } \\
\text { Libicki }\end{array}$ & $26 \%$ \\
\hline Phillips 2014 & $\begin{array}{l}633 \text { groups. Global, 1987- } \\
2005\end{array}$ & $\begin{array}{l}\text { RAND and } \\
\text { GTD }\end{array}$ & $28 \%$ \\
\hline $\begin{array}{l}\text { Young and } \\
\text { Dugan } 2014\end{array}$ & $\begin{array}{l}\text { 2,223 groups. Global, 1970- } \\
2010 .\end{array}$ & GTD & $68 \%$ \\
\hline Miller 2016 & $\begin{array}{c}2,437 \text { groups. Global. 1970- } \\
2013\end{array}$ & GTD & $71 \%$ \\
\hline $\begin{array}{l}\text { Average of data } \\
\text { sets }\end{array}$ & & & $52 \%$ \\
\hline
\end{tabular}


Figure 1. First-year failure rate by group motivation in different data sets

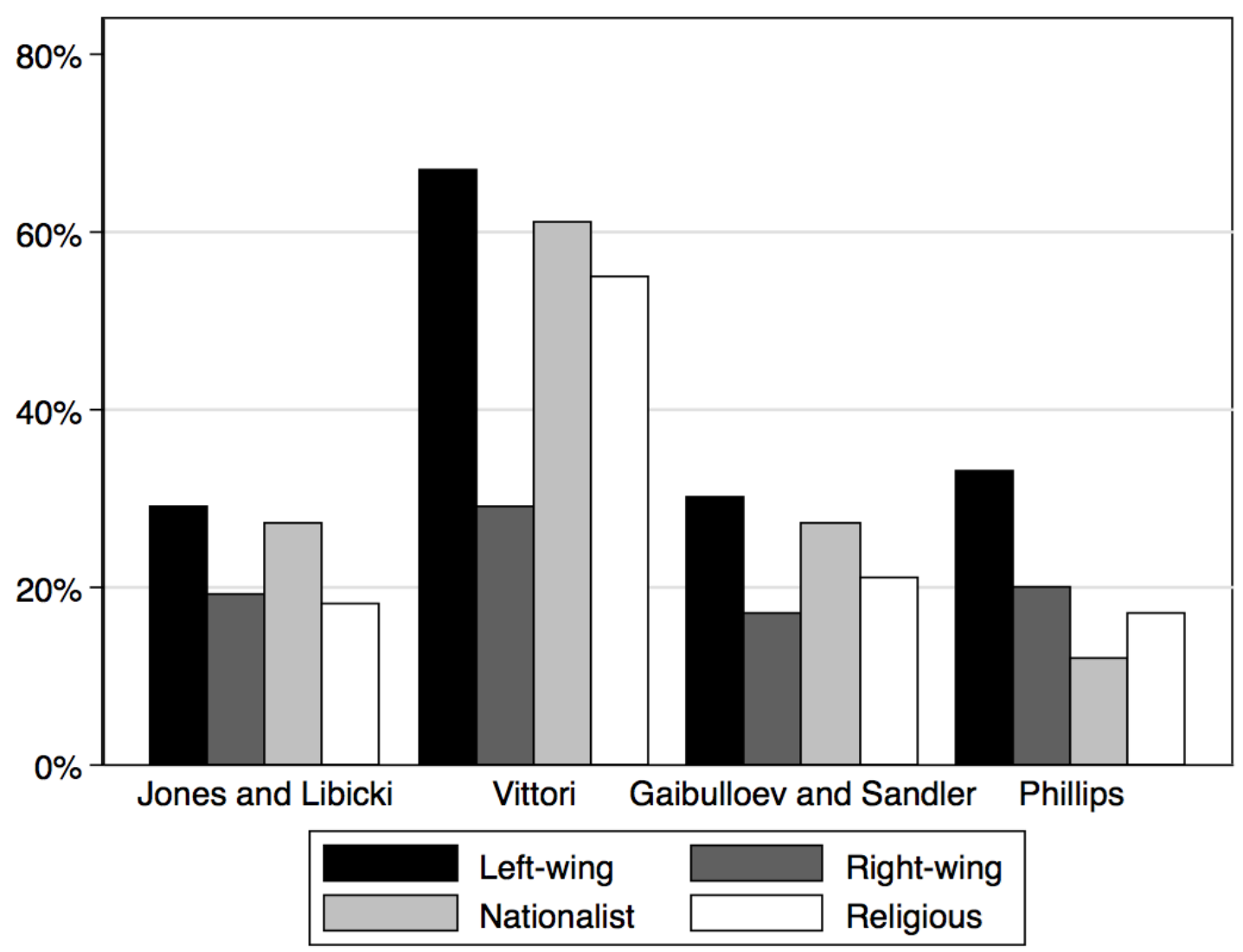

Note: Only studies with information on group motivation for all groups are included. Studies are shown in order of year of publication. 


\section{Notes}

${ }^{1}$ Martha Crenshaw, "The Psychology of Terrorism: An Agenda for the 21st Century," Political Psychology 21, no. 2 (June 1, 2000): 405.

${ }^{2}$ Andrew Silke, "The Devil You Know: Continuing Problems with Research on Terrorism," Terrorism and Political Violence 13, no. 4 (2001): 1-14; Andrew Silke, "Contemporary Terrorism Studies: Issues in Research," in Critical Terrorism Studies: A New Research Agenda, ed. Richard Jackson, Marie Breen Smyth, and Jeroen Gunning (London: Routledge, 2009).

${ }^{3}$ Marc Sageman, "The Stagnation in Terrorism Research," Terrorism and Political Violence no. 25 (4): 565-580. Sageman makes this statement about the topic of radicalization in particular.

${ }^{4}$ Erica Chenoweth, "Terrorism and Democracy," Annual Review of Political Science 16 (2013): 355-378; Khusrav Gaibulloev, James A. Piazza, and Todd Sandler, "Regime Types and Terrorism," International Organization forthcoming; Burcu Savun and Brian J. Phillips, "Democracy, Foreign Policy, and Terrorism," Journal of Conflict Resolution 53 (6): 878-904.

${ }^{5}$ Corner, Emily, and Paul Gill. “A False Dichotomy? Mental Illness and Lone-Actor Terrorism." Law and Human Behavior 39, no. 1 (2015): 23-34.

${ }^{6}$ David C. Rapoport, "Terrorism," in Encyclopedia of Government and Politics, ed. Mary Hawkesworth and Maurice Kogan, vol. 2 (London: Routledge, 1992). Crenshaw analyzed the longevity of a global sample of terrorist groups in an article published in 1991, but this sample was not as comprehensive as later databases. See Martha Crenshaw, "How Terrorism Declines," Terrorism and Political Violence 3, no. 1 (1991): 69-87. ${ }^{7}$ Daniel Byman, The Five Front War: The Better Way to Fight Global Jihad (John Wiley \& Sons, 2008); Audrey Kurth Cronin, "How Al-Qaida Ends: The Decline and Demise of Terrorist Groups," International Security 31, no. 1 (2006): 7-48; Bruce Hoffman, Inside Terrorism (New York, NY: Columbia University Press, 2006); Daniel G. Arce and Todd Sandler, "Terrorist Spectaculars: Backlash Attacks and the Focus of Intelligence," Journal of Conflict Resolution 54, no. 2 (April 1, 2010): 354-73; Andrew Silke, "The Psychology of Counter-Terrorism: Critical Issues and Challenges," in The Psychology of CounterTerrorism, ed. Andrew Silke (London and New York: Routledge, 2011); Jessica Stern, "Radicalization to Extremism and Mobilization to Violence What Have We Learned and What Can We Do about It?," The ANNALS of the American Academy of Political and Social Science 668, no. 1 (November 1, 2016): 102-17.

${ }^{8}$ Bryan C. Price, "Targeting Top Terrorists: How Leadership Decapitation Contributes to Counterterrorism," International Security 36, no. 4 (2012): 37-38.

${ }^{9}$ Jodi Vittori, "All Struggles Must End: The Longevity of Terrorist Groups," Contemporary Security Policy 30, no. 3 (2009): 444-66; Benjamin Acosta, "Live to Win Another Day: Why Many Militant Organizations Survive Yet Few Succeed," Studies in Conflict \& Terrorism 37, no. 2 (February 2014): 135-61; Khusrav Gaibulloev and Todd Sandler, "Determinants of the Demise of Terrorist Organizations," Southern Economic Journal 79, no. 4 (April 1, 2013): 774-92.

${ }^{10}$ A few longevity studies note - literally, in a foot or end note - that their own data seem to disconfirm Rapoport's 90 percent statistic. However, this has not slowed the repetition of the statistic in the literature. 
${ }^{11}$ Rapoport (see note 6 above), 1067.

${ }^{12}$ Hoffman (see note 7 above), 241.

${ }^{13}$ Cronin (see note 7 above), 13.

${ }^{14}$ Max Abrahms, “Are Terrorists Really Rational? The Palestinian Example," Orbis 48, no. 3 (June 2004): 543; Arce and Sandler (see note 7 above); Cristina Archetti,

"(Mis)Communication Wars: Terrorism, Counterterrorism and the Media,", in Propaganda, Power and Persuasion: From the First World War to Wikileaks, ed. David Welch (London: IB Tauris, 2013), 209-24, http://usir.salford.ac.uk/32812/; Byman (see note 2 above) 17; S. Brock Blomberg, Rozlyn C. Engel, and Reid Sawyer, "On the Duration and Sustainability of Transnational Terrorist Organizations," Journal of Conflict Resolution 54, no. 2 (2010): 303-30; Erica Chenoweth et al., "Correspondence: What Makes Terrorists Tick," International Security 33, no. 4 (2009): 180-202; Steven Chermak, Joshua Freilich, and Michael Suttmoeller, "The Organizational Dynamics of Far-Right Hate Groups in the United States: Comparing Violent to Nonviolent Organizations," Studies in Conflict \& Terrorism 36, no. 3 (March 1, 2013): 193-218; Jackson Cothren et al., "Geospatial and Temporal Patterns of Preparatory Conduct among American Terrorists," International Journal of Comparative and Applied Criminal Justice 32, no. 1 (March 1, 2008): 27; Reid Sawyer and Michael Foster, "The Resurgent and Persistent Threat of Al Qaeda," The ANNALS of the American Academy of Political and Social Science 618, no. 1 (July 1, 2008): 197-211; Nadir Gergin, Haci Duru, and Hakan Cem Çetin, "Profile and Life Span of the PKK Guerillas," Studies in Conflict \& Terrorism 38, no. 3 (March 4, 2015): 219-32; Elena V. McLean et al., "Economic Sanctions and the Dynamics of Terrorist Campaigns," Conflict Management and Peace Science, March 11, 2016 (OnlineFirst); João Ricardo Faria and Daniel Arce, "A Vintage Model of Terrorist Organizations," Journal of Conflict Resolution 56, no. 4 (August 1, 2012): 629-50; Arjun Chowdhury and Scott Fitzsimmons, "Effective but Inefficient: Understanding the Costs of Counterterrorism," Critical Studies on Terrorism 6, no. 3 (December 1, 2013): 449,; Shalin Hai-Jew, "Human Rights, the Global War on Transnational Terror, and the Mixed Roles of ICT: A MetaAnalysis," in Human Rights and Risks in the Digital Era: Globalization and the Effects of Information Technologies: Globalization and the Effects of Information Technologies, ed. Christina M. Akrivopoulou and Nicolaos Garipidis (Hershey, PA: Information Science Reference, n.d.); Bruce Hoffman, "A Counterterrorism Strategy for the Obama Administration," Terrorism and Political Violence 21, no. 3 (June 29, 2009): 359-77; Joshua Kilberg, "Organizing for Destruction: How Organizational Structure Affects Terrorist Group Behaviour" (Doctoral dissertation, Carleton University, 2011); Kevin E. Klein, From Assassins to Al-Qaeda: Understanding and Responding to Religious Terrorism (Ottowa, Canada: Canadian Special Forces Command, 2013), 18; Silke, "The Psychology of Counter-Terrorism: Critical Issues and Challenges" (see note 7 above) 5; Alessandro Orsini, "Poverty, Ideology and Terrorism: The STAM Bond," Studies in Conflict \& Terrorism 35, no. 10 (October 1, 2012): 665-92; Price (see note 8 above); Magnus Ranstorp, Mapping Terrorism Research: State of the Art, Gaps and Future Direction (Routledge, 2006), 83; Clark McCauley, "Group Desistance from Terrorism: A Dynamic Perspective," Dynamics of Asymmetric Conflict 1, no. 3 (November 1, 2008): 269-93; Jessica Stern, "ISIL and the Goal of Organizational Survival," in Beyond Convergence: World Without Order, ed. Hilary Matfess and Michael Miklaucic 
(Washington, D.C.: National Defense University Center for Complex Operations, 2016); Stern (see note 7 above); Kelly R. Damphousse, Brent L. Smith, and Amy Sellers, "The Targets and Intended Victims of Terrorist Activities in the United States.," in Meeting the Challenges of Global Terrorism: Prevention, Control, and Recovery, ed. Dilip K. Das and Peter C. Kratcoski (Lexington Books, 2003), 171-88; Dipak K. Gupta, "Waves of International Terrorism," in Terrorism, Identity, and Legitimacy: The Four Waves Theory and Political Violence, ed. Jean E. Rosenfeld (London: Routledge, 2011); Michael J. Suttmoeller, Steven M. Chermak, and Joshua D. Freilich, "Only the Bad Die Young: The Correlates of Organizational Death for Far-Right Extremist Groups," Studies in Conflict \& Terrorism 39, no. 6 (June 2, 2016): 477-99; Anthony J. Wragg, "An Analysis of the Effect of Ideology on the Life Expectancy of Terrorist Organisations" (Master's thesis, Royal Melbourne Institute of Technology, 2008); Vittori (see note 9 above).

${ }^{15}$ While analyzing research citing Rapoport, I found several other errors. For example, some studies have misquoted or exaggerated Rapoport's original claim. One study, with an attribution to Rapoport, states that "well over 90 percent" of terrorist groups survive less than a year. Rapoport's claim is more careful, saying "perhaps as many as 90 percent" (emphasis added).

${ }^{16}$ The 9/11 Commission Report: Final Report of the National Commission on Terrorist Attacks Upon the United States (Government Printing Office, 2011), 169.

${ }^{17}$ Robert Pape, Dying to Win: The Strategic Logic of Suicide Terrorism (New York: Random House, 2005), 6.

${ }^{18}$ Rapoport, "Terrorism," in Encyclopedia of Government and Politics (Mary Hawkesworth and Maurice Kogan, eds.) (London: Routledge, 2004), 1064.

${ }^{19}$ Rapoport, note 18 above, 1067.

20 e.g., Price (see note 8 above), 25; Audrey Kurth Cronin, How Terrorism Ends: Understanding the Decline and Demise of Terrorist Campaigns (Princeton: Princeton University Press, 2009), 208.

${ }^{21}$ Seth G. Jones and Martin C. Libicki, How Terrorist Groups End: Lessons for Countering Al Qa'ida (Washington, D.C.: RAND, 2008); Vittori, “All Struggles Must End: The Longevity of Terrorist Groups"; Blomberg, Engel, and Sawyer (see note 14 above); Gaibulloev and Sandler (see note 9 above); Laura Dugan, "The Making of the Global Terrorism Database and Its Applicability to Studying the Life Cycles of Terrorist Organizations," in The SAGE Handbook of Criminological Research Methods, ed. David Gadd, Susanne Karstedt, and Steven F. Messner (Los Angeles: SAGE, 2012); Brian J. Phillips, "Terrorist Group Cooperation and Longevity," International Studies Quarterly 58, no. 2 (2014): 336-47; Joseph K. Young and Laura Dugan, "Survival of the Fittest: Why Terrorist Groups Endure," Perspectives on Terrorism 8, no. 2 (2014); Erin Miller, "Patterns of Collective Desistance from Terrorism: Fundamental Measurement Challenges,"

Perspectives on Terrorism 10, no. 5 (October 24, 2016), http://www.terrorismanalysts.com/pt/index.php/pot/article/view/538.

22 e.g., David B. Carter, "A Blessing or a Curse? State Support for Terrorist Groups," International Organization 66, no. 1 (2012): 129-51. Ursula E. Daxecker and Michael L. Hess. "Repression Hurts: Coercive Government Responses and the Demise of Terrorist Campaigns.” British Journal of Political Science 43, no. 3 (2013): 559-577. 
${ }^{23}$ The authors also use this database of groups in an article examining determinants of different ways groups can end (e.g., splintering from internal reasons or being defeated by force). Khusrav Gaibulloev and Todd Sandler. "An Empirical Analysis of Alternative Ways that Terrorist Groups End." Public Choice 160, no. 1-2 (2014): 25-44.

${ }^{24}$ Victor Asal and R. Karl Rethemeyer, "The Nature of the Beast: Organizational Structures and the Lethality of Terrorist Attacks," Journal of Politics 70, no. 2 (2008): 437-49.

${ }^{25}$ Brian J. Phillips, "What Is a Terrorist Group? Conceptual Issues and Empirical Implications," Terrorism and Political Violence 27, no. 2 (March 15, 2015): 225-42. For additional discussion and graphical depiction, see Brian J. Phillips, "What Is a Terrorist Group? Concepts and Measurement." Blog post. Duck of Minerva. Feb. 16, 2015. http://duckofminerva.com/2015/02/what-is-a-terrorist-group-concepts-andmeasurement.html

${ }^{26}$ For example, the Global Terrorism Database includes attacks by actors such as the Knights Templar, the Gulf Cartel, and the Medellin and Cali Cartels. See: http://www.start.umd.edu/gtd/search/Results.aspx?search=cartel\&sa.x=0\&sa.y=0\&sa=Sear ch

${ }^{27}$ On longevity variation among U.S. right-wing groups, see Michael J. Suttmoeller, Steven M. Chermak, and Joshua D. Freilich. "Is More Violent Better? The Impact of Group Participation in Violence on Group Longevity for Far-Right Extremist Groups." Studies in Conflict \& Terrorism forthcoming.

${ }^{28}$ e.g., Phillips, "Terrorist Group Cooperation and Longevity," see note 21 above).

${ }^{29}$ S. Brock Blomberg, Khusrav Gaibulloev, and Todd Sandler, "Terrorist Group Survival: Ideology, Tactics, and Base of Operations," Public Choice 149, no. 3-4 (2011): 441-63; Carter (see note 22 above)

${ }^{30}$ Michael G. Findley and Joseph K. Young, "More Combatant Groups, More Terror?: Empirical Tests of an Outbidding Logic," Terrorism and Political Violence 24, no. 5 (2012): 706-21; Stephen Nemeth, "The Effect of Competition on Terrorist Group Operations," Journal of Conflict Resolution 58, no. 2 (2014): 336-62; Kevin Whitmeyer, "Religious Outbidding in Chechnya," Caucasus Survey 3, no. 1 (January 2, 2015): 25-40. ${ }^{31}$ Silke, "The Devil You Know: Continuing Problems with Research on Terrorism," see note 2 above); Silke, "Contemporary Terrorism Studies: Issues in Research," see note 2 above).

32 John J. Mearsheimer and Stephen M. Walt, "Leaving Theory behind: Why Simplistic Hypothesis Testing Is Bad for International Relations," European Journal of International Relations 19, no. 3 (September 1, 2013): 427-57. 